\title{
Problem Pengaturan Upaya Paksa Penangkapan Terhadap Pelaku Tindak Pidana Narkotika
}

\author{
Kholilur Rahman \\ Magister Ilmu Hukum Universitas Airlangga Surabaya Indonesia \\ Jln. Dharmawangsa Dalam Surabaya Indonesia 60286 \\ kholilurrahman844@gmail.com
}

Received: 13 Maret 2020; Accepted: 3 Abgustus 2020; Published: 15 Desember 2020

https://doi.org/10.20885/iustum.vol27.iss3.art3

\begin{abstract}
One of the highlights in Law Number 35 of 2009 on Narcotics, is that there are 2 institutions authorized to carry out investigations, namely the National Narcotics Agency $(B N N)$ and the Indonesian National Police. BNN investigators in the authority to attempted forced arrest using the legal basis of Article 76 of Law no. 35 of 2009 on Narcotics, while the Police investigators use Article 19 paragraph (1) of the Criminal Procedure Code. Police investigators are only authorized to make arrests with a period of $1 \times 24$ hours, not 6 (six) days as the authority of BNN investigators. This difference in arrangement certainly creates legal uncertainty. This research will discuss, first, the implications of the difference in the regulation of the authority for forced arrest by BNN investigators and the National Police for narcotics offenders. Second, the harmonization of arrangements for the forced arrest of narcotics offenders by BNN investigators and the National Police. The research method used is normative, using a statutory approach and a conceptual approach. The results of the study conclude that first, the difference in the regulation of the authority for forced arrest between BNN investigators and the National Police has resulted in different interpretations in its implementation, resulting in legal uncertainty and violations of the principle of equality before the law against narcotics offenders. Second, the disharmony of regulating the forced arrest of narcotics offenders by BNN and Police investigators needs to be harmonized based on the Criminal Procedure Code outlined in the integrated criminal justice system.
\end{abstract}

Key Words: Problem; the force arrest; narcotics

\section{Abstrak}

Salah satu yang menarik dalam Undang-Undang Nomor 35 Tahun 2009 tentang Narkotika, ialah adanya 2 lembaga yang berwenang melakukan penyidikan, yakni Badan Narkotika Nasional (BNN) dan Kepolisian Negara Republik Indonesia. Penyidik BNN dalam kewenangan upaya paksa penangkapan menggunakan dasar hukum Pasal 76 UU No. 35 Tahun 2009 tentang Narkotika, sedangkan penyidik Polri menggunakan Pasal 19 ayat (1) KUHAP. Penyidik Polri hanya berwenang melakukan penangkapan dengan jangka waktu 1 × 24 jam saja, bukan 6 (enam) hari sebagaimana kewenangan Penyidik BNN. Perbedaan pengaturan ini tentu menimbulkan ketidakpastian hukum. Penelitian ini akan membahas, pertama, implikasi perbedaan pengaturan kewenangan upaya paksa penangkapan oleh penyidik BNN dan Polri terhadap pelaku tindak pidana narkotika. Kedua, harmonisasi pengaturan upaya paksa penangkapan terhadap pelaku tindak pidana narkotika oleh penyidik BNN dan Polri. Metode penelitian yang digunakan bersifat normatif, menggunakan pendekatan perundang-undangan (Statute Approach) dan pendekatan konseptual (Conceptual Approach). Hasil penelitian menyimpulkan pertama, perbedaan pengaturan kewenangan upaya paksa penangkapan antara penyidik BNN dan Polri menimbulkan perbedaan penafsiran dalam pelaksanaannya, sehingga berakibat pada ketidakpastian hukum serta pelanggaran prinsip persamaan di muka hukum terhadap pelaku tindak pidana narkotika. Kedua, disharmonisasi pengaturan upaya paksa penangkapan terhadap pelaku tindak pidana narkotika oleh penyidik BNN dan Polri ini perlu diharmonisasikan berdasarkan KUHAP yang digariskan dalam integrated criminal justice system.

Kata-kata Kunci: Problem; upaya paksa penangkapan; narkotika 


\section{Pendahuluan}

Perhatian dunia internasional terhadap penyalahgunaan narkotika, dapat dilihat dari beberapa konvensi internasional yang secara eksplisit menyatakan perang terhadap penyalahgunaan narkotika. Narkotika merupakan International Crime yang harus dilawan secara bersama-sama. ${ }^{1}$ Badan Narkotika Nasional yang selanjutnya disebut sebagai BNN dibentuk dalam rangka pencegahan dan pemberantasan penyalahgunaan dan peredaran gelap narkotika dan prekursor narkotika dengan UU No. 35 Tahun 2009.2 BNN merupakan lembaga pemerintahan non kementerian yang berkedudukan di bawah Presiden dan bertanggungjawab kepada Presiden. BNN berkedudukan di ibu kota negara dengan wilayah kerja meliputi seluruh wilayah Negara Republik Indonesia, dan mempunyai perwakilan di daerah Provinsi dan Kabupaten/Kota. ${ }^{3}$

UU No. 35 Tahun 2009 tentang Narkotika disahkan pada 14 September 2009 yang merupakan revisi dari UU No. 22 Tahun 1997 tentang Narkotika. Secara substansial undang-undang narkotika yang baru tersebut tidak mengalami perubahan yang signifikan bila dibandingkan dengan undang-undang terdahulu. Terkecuali penekanan pada kewenangan upaya paksa pada BNN yang sangat besar. Ketentuan lain disebutkan dalam Undang-Undang No. 2 Tahun 2002 tentang Kepolisian Republik Indonesia pada Pasal 14 butir g menyatakan bahwa "Kepolisian bertugas melakukan penyelidikan dan penyidikan terhadap semua tindak pidana sesuai dengan hukum acara pidana dan peraturan perundang-undangan".

Kewenangan penyidik Polri tidak secara rinci diatur dalam UU No. 35 Tahun 2009 tentang Narkotika, melainkan hanya disebutkan dalam Pasal 81 UU No. 35 Tahun 2009 tentang Narkotika yang mengatur bahwa Kepolisian Republik Indonesia dengan Badan Narkotika Nasional juga diberi kewenangan melakukan penyidikan terhadap tindak pidana narkotika. Ketentuan tersebut menimbulkan penafsiran bahwa penyidik Polri dapat melaksanakan penyidikan berdasarkan undang-undang ini (UU No. 35 Tahun 2009 tentang Narkotika), tetapi undangundang tersebut hanya secara tegas mengatur kewenangan Penyidik BNN

1 Sukardi, Penyidikan Tindak Pidana, Restu Agung, Restu Agung, Jakarta, 2009, hlm. 139.

2 Siswanto, Politik Hukum dalam Undang-Undang Narkotika (UU Nomor 35 Tabun 2009), Rineka Cipta, Jakarta, 2012, hlm. 297.

3 Ibid. 
sebagaimana diatur dalam Pasal 75 UU No. 35 Tahun 2009 tentang Narkotika mulai dari huruf a sampai dengan huruf s. Sedangkan kewenangan penyidikan yang dimiliki oleh Kepolisian Republik Indonesia sesuai dengan yang telah diamanatkan dalam KUHAP. Sehingga dasar hukum yang digunakan penyidik Polri dengan penyidik BNN berbeda terkait dengan hukum pidana formilnya, salah satunya pada prosedur upaya paksa penangkapan.

Penyidik BNN dalam menjalankan kewenangan waktu penangkapan yang diatur dalam Pasal 76 Undang-Undang Nomor 35 Tahun 2009 tentang Narkotika yaitu 3 × 24 jam dan dapat diperpanjang paling lama 3 × 24 jam, sedangkan penyidik Kepolisian Republik Indonesia kembali kepada Pasal 19 ayat (1) KUHAP yakni paling lama 1 × 24 jam. ${ }^{4}$ Pengaturan kewenangan upaya paksa penangkapan antara penyidik BNN dan Polri ini sering menimbulkan perbedaan penafsiran dalam pelaksanaannya. Pengaturan kewenangan masa penangkapan antara Penyidik BNN dan Polri tersebut dipandang membeda-bedakan tersangka sehingga menimbulkan ketidakpastian hukum serta melanggar prinsip persamaan di muka hukum bagi para tersangka yang ditangkap oleh penyidik BNN dan tersangka yang ditangkap oleh penyidik Polri. ${ }^{5}$ Mengingat UU No. 35 Tahun 2009 tentang Narkotika merupakan Lex Specialis dari KUHAP, tentu perlu dilakukan kajian perubahan untuk mengatur kewenangan penangkapan yang sama, serta pengaturan penegakan tindak pidana narkotika diatur diluar KUHAP.

Permasalahan di atas perlu diharmonisasikan berdasarkan sistem peradilan pidana terpadu guna menjaga harmonisasi dan mengatasi tumpang tindih peraturan perundang-undangan. KUHAP dalam sistem peradilan pidana yang

\footnotetext{
4 Mengingat, bahwa UU No. 35 Tahun 2009 tentang Narkotika merupakan Lex specialis dari Kitab Undang-Undang Hukum Acara Pidana artinya penyalahgunaan narkotika adalah tindak pidana khusus yang pengaturannya dipisahkan dari KUHAP.

${ }^{5}$ Permasalahan kewenangan ini dihawatirkan berpotensi menjadi polemik institusional yang patut menjadi perhatian, karena soal kewenangan menyangkut masalah gengsi institusional. Institusi dapat dianggap tidak mampu dan tidak cakap dalam melaksanakan kekuasaan yang diberikan,bahkan dianggap tidak pernah memberikan akuntabilitas memadai sesuai dengan harapan masyarakat apalagi kewenangan ini menyangkut kekuasaan. Ibaratnya the elimination of power is a show of power, akibatnya yang timbul adalah arogansi institusional sekaligus egoisme struktural sehingga akan menggangu proses integrated criminal justice system secara komprehensif. Lihat Indriyanto Seno Adji, "Dwang Middelen dan Ide Arah Hakim Komisaris", dalam Media Hukum, Volume 1 No. 522 April 2003, 2003, hlm. 77-78, dalam M. Sahid, "Rekonstruksi Kewenangan Penyidikan Badan Narkotika Nasional Berdasarkan Undang-Undang Nomor 35 Tahun 2009 Tentang Narkotika”, dalam Arena Hukum, Vol 7, No 3, 2014, hlm, 347-348.
} 
digariskan merupakan "sistem terpadu" (integrated criminal justice system). ${ }^{6}$ Sistem terpadu tersebut diletakkan di atas landasan prinsip "diferensiasi fungsional" diantara penegak hukum sesuai dengan "tahap proses kewenangan" yang diberikan undang-undang dan tunduk pada prinsip the right of due process.

Penyidik Polri hanya berhak melakukan penangkapan dengan jangka waktu $1 \times 24$ jam saja, bukan 6 hari sebagaimana kewenangan yang dimiliki Penyidik BNN. Namun pada praktiknya banyak kasus narkotika mengenai kewenangan penangkapan yang dijalankan adalah 6 hari sekalipun tidak disidik oleh Penyidik BNN. Hal tersebut tentunya melanggar prinsip "the right of due process" dalam sistem peradilan pidana terpadu.

Karakter utama upaya paksa penangkapan adalah pengekangan sementara waktu, guna kepentingan penyidikan dan tidak boleh undue process. Upaya paksa penangkapan dengan sendirinya dianggap tidak sah manakala batas waktu tersebut dilanggar atau melebihi batas waktu yang sudah ditentukan. Hal tersebut tentunya menarik untuk diteliti karena penyidik BNN dan penyidik Polri memiliki aturan hukum yang berbeda, karena tata cara "penyelidikan" dan "penyidikan" yang menyimpang dari ketentuan Hukum Acara. Beranjak dari literatur dan berbagai penelitian yang belum tuntas membahas mengenai hal tersebut, untuk itu persoalan terkait perbedaan dan harmonisasi pengaturan upaya paksa penangkapan terhadap pelaku tindak pidana narkotika menjadi penting untuk diteliti melalui penelitian ini. Penelitian ini tentu relevan dalam rangka memperbarui konsep pengaturan upaya paksa dalam penyidikan tindak pidana narkotika di Indonesia.

\section{Rumusan Masalah}

Berdasarkan uraian pada latar belakang di atas, peneliti bermaksud untuk menguraikan dan menjelaskan dengan rumusan permasalahan, pertama, bagaimana implikasi mengenai perbedaan pengaturan kewenangan upaya paksa penangkapan oleh penyidik BNN dan Polri terhadap pelaku tindak pidana narkotika? kedua, bagaimana harmonisasi pengaturan upaya paksa penangkapan terhadap pelaku tindak pidana narkotika oleh penyidik BNN dan Polri?

\footnotetext{
${ }^{6}$ M. Yahya Harahap, Pembahasan Permasalahan dan Penerapan KUHAP, Edisi 2, Cetakan 14, Sinar Grafika, Jakarta, 2012, hlm. 90.
} 


\section{Tujuan Penelitian}

Adapun tujuan dari penelitian ini, yaitu adalah: pertama, untuk mengetahui implikasi dari perbedaan pengaturan upaya paksa penangkapan oleh penyidik BNN dan Polri terhadap pelaku tidak pidana narkotika. Kedua, untuk merumuskan harmonisasi pengaturan upaya paksa penangkapan terhadap pelaku tindak pidana narotika oleh penyidik BNN dan Polri.

\section{Metode Penelitian}

Metode penelitian yang digunakan dalam artikel ini adalah penelitian hukum normatif. Cara pendekatan yang digunakan yakni pendekatan perundang-undangan (Statute Approach) dan pendekatan konseptual (Conceptual Approach). Peneliti juga memanfaatkan hasil-hasil temuan ilmu hukum empiris untuk kepentingan analisis serta eksplanasi hukum tanpa pengubahan karakter ilmu hukum sebagai ilmu normatif. Bahan hukum yang digunakan yaitu bahan hukum primer dan sekunder. Prosedur pengumpulan bahan hukum melalui proses yang bertahap, tahap yang pertama adalah kajian mengenai hukum normatif yang berlaku, berhubungan dengan kewenangan penyidik BNN dan Polri terkait penangkapan tindak pidana narkotika; tahap kedua adalah penerapan pada peristiwa in concreto melalui teknik wawancara, untuk mengetahui upaya paksa penangkapan yang dilakukan oleh penyidik BNN dan Polri.Wawancara dilakukan di BNN Provinsi Jawa Timur dan POLDA Jawa Timur, pada 31 Mei 2019 dengan Kepala Bidang Pemberantasan BNN Provinsi Jawa Timur dan Kepala Bagian Pembinaan dan Operasional Direskrim Narkoba POLDA Jawa Timur. Hasil dari pengumpulan bahan hukum, disajikan dan dianalisis secara kualitatif, kemudian menguraikan fakta yang telah ada sesuai dengan cara berfikir deduktif.

\section{Hasil Penelitian dan Pembahasan}

Implikasi Mengenai Perbedaan Pengaturan Kewenangan Upaya Paksa Penangkapan oleh Penyidik BNN dan Polri Terhadap Pelaku Tindak Pidana Narkotika

Penangkapan merupakan salah satu bentuk dari upaya paksa yang merupakan kewenangan penyidik. Sebagai ketentuan yang bersifat umum (legi generalie), upaya paksa penangkapan diatur dalam KUHAP terhadap semua jenis 
tindak pidana.7 Penyidik dalam KUHAP ialah Pejabat Kepolisian Negara Republik Indonesia atau Pejabat Pegawai Negeri Sipil Tertentu yang diberi wewenang khusus oleh undang-undang untuk melakukan penyidikan. ${ }^{8}$ Ketentuan tersebut memberikan landasan bahwa penyidik dapat ditunjuk secara khusus berdasarkan suatu undang-undang, dalam UU No. 35 Tahun 2009 tentang Narkotika penyidik khusus yang dibentuk adalah Badan Narkotika Nasional. ${ }^{9}$

Pengaturan jangka waktu penangkapan oleh Penyidik BNN dan penyidik Polri justru berbeda, sebagaimana dalam Bab XII Pasal 76 UU No. 35 Tahun 2009 tentang Narkotika. Terdapat beberapa perbedaan mendasar antara regulasi baru ini dengan Undang-Undang Narkotika lama, antara lain:

Table 1.

Perbedaan Pengaturan Penangkapan.

\begin{tabular}{lll}
\hline \multicolumn{1}{c}{ KUHAP } & \multicolumn{1}{c}{ UU Narkotika Lama } & \multicolumn{1}{c}{ UU Narkotika } \\
\hline Penyidik: & Penyidik: & Penyidik : \\
Polri & Polri & BNN \\
PNS Tertentu & PNS Tertentu & Polri \\
& & PNS Tertentu \\
Penangkapan maksimal & Penangkapan maksimal & Penangkapan oleh \\
$1 \times 24$ jam. & $3 \times 24(72)$ jam. & Penyidik BNN maksimal \\
& & $6 \times 24$ jam. \\
\hline
\end{tabular}

Sumber: diolah penulis, 2020.

Terlepas dari cara penangkapan, baik direncanakan ataupun tertangkap tangan, KUHAP mengatur bahwa penangkapan hanya dapat dilakukan untuk jangka waktu 1 hari (Pasal 19 ayat (1) KUHAP). ${ }^{10}$ Tidak ada perpanjangan, benarbenar hanya 1 x 24 jam. Lewat satu hari, berarti telah terjadi pelanggaran hukum, dan dengan sendirinya penangkapan di anggap "tidak sah". Konsekuensinya, tersangka harus dibebaskan demi hukum. ${ }^{11}$

UU No. 22 Tahun 1997 tentang Narkotika yang selanjutnya disebut sebagai UU Narkotika Lama dalam tabel 1, mengatur kewenangan penyidik Polri

Lihat Pasal 16 ayat (2) KUHAP.

8 Lihat Pasal 1 angka 1 KUHAP.

${ }^{9}$ Keberadaan BNN dengan kewenangannya telah mejadikan BNN sebagai lembaga super body dalam mencegah dan memberantas Penyalahgunaan Narkotika dan Prekursor Narkotika. BNN dalam hal ini diberi wewenang melakukan penyidikan terhadap Tindak Pidana Narkotika, disamping dapat juga dilakukan Penyidik Kepolisian.

${ }^{10}$ Ricky Gunawan, et al., Membongkar Praktik. Pelanggaran Hak Tersangka di Tingkat Penyidikan: Studi Kasus Terbadap Tersangka Kasus Narkotia di Jakarta, Cetakan 1, LBH Masyarakat, Jakarta, 2012, hlm. 8.

${ }_{11}$ M. Yahya Harahap, Op. Cit., hlm. 160. 
maksimal 3 x 24 jam (72) jam. Namun dengan dikeluarkannya UU No. 35 Tahun 2009 tentang Narkotika, maka UU Narkotika lama dinyatakan dicabut dan tidak berlaku lagi. Kewenangan penyidik Polri terkait narkotika kemudian hanya mengacu pada aturan lain yaitu KUHAP dan Undang-Undang Kepolisian. Sehingga kewenangan penyidik Polri dalam jangka waktu upaya paksa penangkapan tidak lagi menggunakan 3 x 24 (72) jam.

Pasal 76 UU No. 35 Tahun 2009 tentang Narkotika mengatur ketentuan penangkapan ini secara lengkap yaitu:

Pelaksanaan kewenangan penangkapan sebagaimana dimaksud dalam Pasal 75 huruf $g$ dilakukan paling lama $3 \times 24$ (tiga kali duapuluh empat) jam terhitung sejak surat penangkapan diterima penyidik.

Penangkapan sebagaimana dimaksud pada ayat (1) dapat diperpanjang paling lama $3 \times 24$ (tiga kali duapuluh empat) jam.

Pasal 76 UU Narkotika di atas menerangkan bahwa kekhususan penangkapan ini dalam rangka menjalankan kewenangan penangkapan yang diatur dalam Pasal 76 huruf g UU Narkotika. Pasal 75 Narkotika mengatur kewenangan yang dimiliki oleh Penyidik BNN. Ada 19 kewenangan yang dimiliki oleh Penyidik BNN (huruf a sampai dengan huruf s), dan salah satu kewenangannya (sebagaimana dinyatakan dalam huruf g) adalah untuk menangkap dan menahan orang yang melakukan Penyalahgunaan dan Peredaran Gelap Narkotika dan Prekursor Narkotika. ${ }^{12}$ Artinya, waktu penangkapan penyidik BNN menurut undang-undang tersebut dapat dilakukan sampai selama 6 × 24 jam.

Perpanjangan masa penangkapan sebanyak 2 kali berturut-turut yaitu selama 6 x 24 jam bukanlah kewenangan penyidik Polri melainkan kewenangan penyidik BNN sebagaimana diatur dalam Pasal 76 Junto Pasal 75 huruf g UU No. 35 Tahun 2009 tentang Narkotika dan Pasal 84 UU No. 35 Tahun 2009 tentang Narkotika.

UU No. 35 Tahun 2009 tentang Narkotika yang merupakan "lex specialis de rogat lege generalie" justru tidak secara tegas pengaturannya. ${ }^{13}$ Dalam proses penyidikan, undang-undang tersebut mengatur kewenangan penyidik BNN secara eksplisit

12 Rido Triawan, et al., Membongkar kebijakan narkotika, Cetakan 1, Penerbit Perhimpunan Bantuan Hukum dan Hak Asasi Manusia \& Kemitraan Australia-Indonesia, Jakarta Pusat, 2010, hlm. 62.

${ }^{13}$ Supriyadi Widodo Edyyono, et al., Memperkuat Revisi Undang-Undang Narkotika Indonesia Usulan Masyarakat Sipil, Institute For Criminal Justice Reform, Jakarta, 2017, hlm. 66. 
sehingga terdapat beberapa hal yang secara khusus mengeliminasi kewenangan penyidik Polri. Salah satunya mengenai masa penangkapan maksimal 6 × 24 jam hanya berlaku bagi Penyidik BNN, sedangkan penyidik Polri kembali kepada Pasal 19 ayat (1) KUHAP yakni paling lama 24 jam. ${ }^{14}$

Adanya perbedaan kewenangan upaya paksa penangkapan terhadap pelaku tindak pidana narkotika menjadi suatu persoalan hukum bagi penyidik BNN dan penyidik Polri dalam menentukan penggunaan dasar hukumnya. Hal ini mengingat penyidik Polri hanya berhak melakukan penangkapan dengan jangka waktu 1 × 24 jam saja berdasarkan Pasal 19 ayat (1) KUHAP, bukan 6 hari sebagaimana kewenangan yang dimiliki Penyidik BNN yang di atur dalam Pasal 76 UU No. 35 Tahun 2009 tentang Narkotika. Hal tersebut menimbulkan perbedaan pelaksanaan upaya paksa penangkapan bagi pelaku tindak pidana narkotika oleh Penyidik BNN dan Polri. Perbedaan tersebut tentunya memicu ketidakpastian hukum dan prinsip persamaan di muka hukum.

Sehubungan dengan ketidakpastian hukum yang ditimbulkan, dapat dijelaskan bahwa dalam melaksanakan kewenangan penyelidikan dan penyidikan, penyidik harus taat dan tunduk pada prinsip the right of due process. Setiap tersangka berhak diselidiki dan disidik di atas landasan "sesuai dengan hukum acara", tidak boleh undue process. ${ }^{15}$ UU No. 35 Tahun 2009 tentang Narkotika Penyidik menentukan Polri hanya berhak melakukan penangkapan dengan jangka waktu 1 × 24 jam saja, bukan enam hari sebagaimana kewenangan yang dimiliki Penyidik BNN. Pada praktiknya justru banyak pelaku narkotika yang ditangkap hingga 6 hari sekalipun tidak disidik oleh Penyidik BNN. Contoh kasus tersebut dapat di uraikan dalam halaman 16.

Kewenangan penyidik Polri tidak secara rinci diatur dalam UU No. 35 Tahun 2009 tentang Narkotika, melainkan disebutkan secara menyeluruh dalam Pasal 81 UU No. 35 Tahun 2009 tentang Narkotika. Penyidik Kepolisian Negara Republik Indonesia dan Penyidik BNN berwenang melakukan penyidikan terhadap Penyalahgunaan dan Peredaran Gelap Narkotika dan Prekursor

14 Rido Triawan, et al., Op. Cit., hlm. 64.

15 Permasalahan ini perlu disinggung, karena masih banyak keluhan masyarakat yang disuarakan anggota masyarakat tentang adanya berbagai tata cara "penyelidikan" dan "penyidikan" yang menyimpang dari ketentuan Hukum Acara. Lihat Yahya Harahap, Op. Cit., hlm. 95. 
Norkotika berdasarkan UU No. 35 Tahun 2009 tentang Narkotika. Substansi pasal tersebut dapat ditafsirkan bahwa penyidik Polri dapat melaksanakan penyidikan berdasarkan undang-undang ini (UU No. 35 Tahun 2009 tentang Narkotika), tetapi undang-undang tersebut hanya secara tegas mengatur kewenangan Penyidik BNN yang diatur dalam Pasal 75 UU No. 35 Tahun 2009 tentang Narkotika mulai dari huruf a sampai dengan huruf s. Sedangkan kewenangan penangkapan yang dimiliki oleh Kepolisian Republik Indonesia sebagaimana yang diamanatkan dalam Pasal 16 ayat (1) huruf a KUHAP.

Hal tersebut mengakibatkan perbedaan penafsiran dalam pelaksanaanya, karena Kepolisian Republik Indonesia kurang memperhatikan isi dari Pasal 75 dan Pasal 81 UU No. 35 Tahun 2009 tentang Narkotika.16 Para penegak hukum khususnya kepolisian dan BNN dalam pelaksanaanya sering tidak konsisten dan tidak tegas dalam menentukan penggunaan dasar hukum dalam menjalankan kewenangannya.

Perihal prinsip persamaan di muka hukum, maka penegakan hukum seyogianya menjunjung tinggi rasa keadilan. Tidak boleh ada perbedaan perlakuan antara satu pelaku dengan pelaku yang lain pada saat menghadapi proses hukum. Komisi kepolisian nasional (Kompolnas) sendiri melihat adanya perbedaan paradigma penegakan hukum antara Polri dan BNN, khususnya, perbedaan penindakan para pengguna narkotika. ${ }^{17}$ Disparitas pengaturan kewenangan masa penangkapan antara Penyidik BNN dan Polri dipandang membeda-bedakan tersangka. Ketika disidik oleh penyidik BNN lain pula ketika disidik oleh Penyidik Polri, sehingga menimbulkan ketidakpastian hukum dan melanggar prinsip persamaan di hadapan hukum.

\section{Harmonisasi Pengaturan Upaya Paksa Penangkapan Terhadap Pelaku Tindak Pidana Narkotika oleh Penyidik BNN dan Polri}

Pengertian harmonisasi dalam beberapa literatur dapat dijumpai, antara lain menurut Ahmad M. Ramli, "harmonisasi" berasal dari kata "harmoni", yang

\footnotetext{
16 Dian Puspita Rini, "Kajian Normatif Mengenai Kewenagan Penangkapan oleh Penyidik BNN dan Penyidik Polri Terhadap Tersangka Tindak Pidana Narkotika", Jurnal Hukum Universitas Brawijaya, Mei 2015, hlm. 6-7.

17 "Penegakan Hukum Polri dan BNN berbeda", http://www2.jawapos.com/baca/artikel/17423/ Kompolnas-Penegakan-Hukum-Polri-dan-BNN-Berbeda, Sabtu, 16 Mei 2015, diakses tanggal 18 Juni 2019.
} 
berarti keselarasan, kecocokan, keserasian. ${ }^{18}$ Sedangkan dalam Kamus Besar Bahasa Indonesia (2005) "harmonisasi" diartikan upaya mencari keselarasan. ${ }^{19}$ Dalam konteks hukum, Wahiduddin Adams, mengemukakan:

Bahwa harmonisasi peraturan perundang-undangan adalah upaya untuk menyelaraskan suatu rancangan peraturan perundang-undangan dengan peraturan perundang-undangan lain, baik yang lebih tinggi, sederajat, maupun yang lebih rendah, dan hal-hal lain di luar peraturan perundangundangan, sehingga tersusun secara sistematis, tidak saling bertentangan atau tumpang tindih (overlaping). 20

Harmonisasi peraturan perundang-undangan di dalam suatu sistem hukum mempunyai peranan yang sangat penting dalam menjaga keselarasan dan mencegah tumpang tindihnya peraturan perundang-undangan yang satu dengan yang lainnya. Perbedaan pengaturan kewenangan upaya paksa penangkapan oleh kepolisian dan BNN terhadap pelaku tindak pidana narkotika, perlu kiranya untuk diharmonisasikan berdasarkan prinsip-prinsip yang terdapat dalam sistem peradilan pidana terpadu (integrated criminal justice system).

Sistem peradilan pidana yang digariskan KUHAP merupakan (integrated criminal justice system). Sistem terpadu tersebut diletakkan di atas landasan prinsip "diferensiasi fungsional" di antara penegak hukum sesuai dengan "tahap proses kewenangan" yang diberikan undang-undang kepada masing-masing. ${ }^{21}$

Berdasarkan pelaksanaan proses peradilan pidana yang terdiri atas serangkaian tahap mulai dari penyelidikan, penyidikan, penangkapan, penahanan, penuntutan, pemeriksaan dipersidangan, hingga pemidanaan, merupakan kegiatan yang sangat kompleks. ${ }^{22}$ Penyidik BNN atau Penyidik Polri menjadi pintu gerbang menuju ke peradilan pidana dalam perkara tindak pidana narkotika di Indonesia, sesuai dengan rangkaian pada tahapan yang diawali dengan proses penyelidikan dan penyidikan. Untuk itu dalam melaksanakan

18 Ahmad M. Ramli, Koordinasi dan Harmonisasi Pera-turan Perundang-undangan, dalam Komisi Yudisial Republik Indonesia, Dialektika Pembaruan Sistem Hukum Indonesia, Cetakan Pertama, Sekretariat Jenderal Komisi Yudisial Republik Indonesia, Jakarta, 2012, hlm. 140.

19 M Dahlan al Barry, Kamus Modern Bahasa Indonesia, dalam Ibid., hlm. 140.

20 Komisi Yudisial Republik Indonesia, Op. Cit., hlm. 142.

21 M. Yahya Harahap, Op. Cit., hlm. 90.

22 Penegakan hukum "secara actual" (the actual enforcement law) meliputi tindakan penyelidikan-penyidikan (investigation), penangkapan (arrest) - penahanan (detention), persidangan pengadilan (trial) dan pemidanaan (punishement), LihatIbid. 
kewenangan penyidikan, penyidik tersebut harus taat dan tunduk pada prinsip the right of due process. Setiap tersangka berhak diselidiki dan disidik di atas landasan sesuai dengan hukum acara. Berikut adalah beberapa prinsip untuk melandasi pengharmonisasian hukum acara pidana, khususnya terkait dengan pengaturan penangkapan dalam tindak pidana narkotika.

\section{Prinsip Diferensiasi Fungsional}

Prinsip diferensiasi fungsional, adalah penegasan pembagian tugas wewenang antara jajaran aparat penegak hukum secara instansional. ${ }^{23}$ Pelaksanaan serangkaian kegiatan/upaya paksa yaitu penangkapan, penggeledaan, penyitaan dan pemeriksaan. KUHAP memberikan hak istimewa atau hak previlege kepada penyidik, sehingga segala tindakan yang dilakukan oleh penyidik dapat berjalan secara efektif dan efisien dalam rangka penegakan hukum. KUHAP juga meletakkan suatu asas "penjernihan" (clarification) dan "modifikasi" (modification) fungsi dan wewenang antara instansi penegak hukum. ${ }^{24}$

Penjernihan diferensiasi fungsi dan wewenang ini diarahkan antara "penyidik BNN dan Polri” sebagaimana Pasal 81 UU No. 35 Tahun 2009 tentang Narkotika. Penjernihan yang tegas diperlukan antara fungsi dan wewenang Badan Narkotika Nasional sebagai penyidik dan Kepolisian Republik Indonesia yang juga sebagai penyidik. Perbandingan ketentuan pembagian diferensiasi fungsi kewenangan penangkapan dalam Undang-Undang Narkotika (UU No. 35 Tahun 2009 tentang Narkotika) dengan yang diatur dalam KUHAP (Undang-Undang Nomor 8 Tahun 1981 tentang Hukum Acara Pidana) lebih menjelaskan mengenai perlunya penjernihan ini. Pasal 81 UU No. 35 Tahun 2009 tentang Narkotika menyebutkan:

Penyidik Kepolisian Negara Republik Indonesia dan penyidik BNN berwenang melakukan penyidikan terhadap penyalahgunaan dan peredaran gelap Narkotika dan Prekursor Narkotika berdasarkan Undang-Undang ini.

Tampak begitu ruwet adanya campur aduk fungsi penyidikan, karena dalam penyidikan kasus narkotika Polisi bukan lagi penyidik tunggal, melainkan bersama-sama dengan BNN. Yang menjadi permasalahan adalah Pasal 81 UU No.

23 Ibid., hlm. 47

${ }^{24}$ Ibid. 
35 Tahun 2009 tentang Narkotika, yang menyebutkan bahwa penyidik Polri dan penyidik BNN berwenang melakukan penyidikan berdasarkan undang-undang ini. Namun undang-undang tersebut tidak mengatur secara jelas dan tegas kewenangan penyidik Polri, sehingga kewenangan penyidik Polri dalam upaya paksa penangkapan kembali menggunakan KUHAP.

Campur aduk atau ketidakjernihan fungsi penyidikan khususnya pada taraf penangkapan mestinya diperbaiki dengan memberi landasan diferensiasi fungsi secara institusional. Hal itu dilakukan dengan menegaskan dan memberi wewenang kepada Kepolisian sebagai instansi penyidik "tunggal" dengan jangka waktu penangkapan menggunakan KUHAP sebagai dasar hukumnya, yaitu 1 x24 jam. Sementara BNN dijernihkan wewenangnya untuk memberantas jaringan narkotika, dengan menggunakan dasar hukum yang diatur dalam UU No. 35 Tahun 2009 tentang Narkotika dengan jangka waktu penangkapan adalah $6 \times 24$ jam.

Polri dan Badan Narkotika Nasional (BNN) perlu pembagian kewenangan yang jelas, seperti KPK dengan Polri atau Kejaksaan, agar masyarakat tidak bingung sekaligus menjadi pembeda terkait kualitas kinerja masing-masing pihak. ${ }^{25}$ Peradilan Indonesia merupakan suatu sistem, artinya harus dilihat, diterima, dan diterapkan sebagai suatu kesatuan yang terdiri dari bagian-bagian yang tidak boleh bertetangan. ${ }^{26}$ Selain prinsip diferensiasi fungsional, M. Yahya Harahap mengungkapkan sebagai berikut.

KUHAP telah menggariskan pembagian tugas wewenang masing-masing instansi aparat penegak hukum, akan tetapi, sekalipun KUHAP menggariskan pembagian wewenang secara instansional, KUHAP sendiri memuat ketentuan yang menjalin instansi-instansi penegak hukum dalam suatu hubungan kerja sama yang di titik beratkan bukan hanya untuk menjernihkan tugas wewenang dan efisiensi kerja, tetapi juga diarahkan untuk terbina suatu tim atau aparat penegak hukum yang dibebani tugas dan tanggung jawab saling mengawasi dalam "sistem ceking" antara sesama mereka. ${ }^{27}$

Kewenangan BNN dengan Kepolisian Negara Republik Indonesia bila dikaji dari perspektif sistem peradilan pidana yakni sebagai kesatuan sistem yang integral, sehingga pembagian kewenangan penyidikan harus jelas agar tidak

25 "Polri dan BNN perlu Pembagian Kerja Jelas" https://www.republika.co.id/berita/breakingnews/nasional/11/03/14/169312-polri-dan-bnn-perlu-pembagian-kerja-jelas, diakses tanggal 04 Maret 2020.

26 Ahmad Ali, Loc. Cit.

${ }^{27}$ Yahya Harahap, Op. Cit., hlm. 49. 
terjadi tumpang tindih. Salah satu karakteristik dari sistem peradilan pidana terpadu (integrated criminal justice system) adalah sinkronisasi, baik sinkronisasi struktural, substansial, maupun kultural. ${ }^{28}$

Hebert L. Packer menyatakan bahwa para penegak hukum dalam sistem peradilan pidana adalah integrated criminal justice system yang tidak dapat dipisahpisahkan, sehingga antara tugas penegak hukum yang satu dengan lainnya saling berkaitan. ${ }^{29}$ Manakala ditinjau dari segi menajemen, pelaksanaan penegakan hukum yang melibatkan beberapa instansi organisasi dalam proses pelaksanaan sesuai dengan fungsi dan wewenang masing-masing, jelas memerlukan "modifikasi" dan "klarifikasi". Namun dalam peningkatan modifikasi dan klarifikasi fungsi dan wewenang, jangan sampai menimbulkan instansi sentris. Setiap instansi aparat harus merupakan "subsistem" yang mendukung "total sistem" proses penegakan hukum dalam suatu kesatuan yang menyeluruh. ${ }^{30}$

\section{Prinsip Due Process of Law}

Pengertian due process of lawadalah proses hukum yang benar atau adil yang merupakan prinsip Hukum Acara Pidana di Indonesia. Penyidik dalam melaksanakan kewenangan penyelidikan dan penyidikan harus taat dan tunduk pada prinsip the right of due process, setiap tersangka berhak diselidiki dan disidik di atas landasan "sesuai dengan hukum acara", tidak boleh undue process. ${ }^{31}$ Hak due procces dalam melaksanakan tindakan penegakan hukum, bersumber dari cita-cita "Negara Hukum" yang menjunjung tinggi "supremasi hukum" (the law is supreme), bahwa: "kita diperintah oleh hukum" dan "bukan oleh orang" (government of law and not of men). ${ }^{32}$

Penyidik BNN dalam hal melaksanakan kewenangan penangkapan terhadap orang yang diduga melakukan peredaran gelap narkotika dan prekursor narkotika, menggunakan Pasal 76 Undang-UndangNarkotika.

28 Shinta Agustina, "Implementasi Asas Lex Specialis Derogat Legi Generali dalam Sistem Peradilan Pidana", Jurnal Masalab-Masalah Hukum, Vol. 44, No. 4, 2015, hlm. 504.

29 "Beberapa Catatan RUU KUHAP Dalam Hubungannya Dengan Pemberantasan Tindak Pidana Korupsi - Eddy O.S Hiariej", https://antikorupsi.org/sites/default/files/doc/Umum/Eddy $\% 200 S \% 20$ HiariejBeberapa $\% 20$ Catatan $\% 20$ RUU $\% 20$ KUHAP $\% 20$ dalam $\% 20$ Hubungannya $\% 20$ dengan $\% 20$ Pemberantasan $\% 20$ Ti ndak $\% 20$ Pidana $\% 20$ Korupsi.pdf, diakses tanggal 25 Maret 2020.

30 Yahya Harahap, Op. Cit., hlm. 62.

31 Ibid., hlm. 95.

32 Ibid. 
Ketentuan tersebut merupakan penjelasan dari kewenangan Penyidik BNN yang tercantum dalam Pasal 75 huruf g, dan dapat dilakukan paling lama 3 × 24 Jam terhitung sejak surat penangkapan diterima penyidik dan dapat diperpanjang paling lama $3 \times 24$ jam. Menjadi pertanyaan pula apakah Penyidik Polri dapat menggunakan kewenangan yang sama dalam hal kewenangan penangkapan dikarenakan dalam undang-undang menyebutkan bahwa kewenangan tersebut adalah kewenangan Penyidik BNN.

Penyidik Polri dalam melaksanakan upaya paksa penangkapan sering menggunakan dasar hukum UU No. 35 Tahun 2009 tentang Narkotika, dengan jangka waktu 3 × 24 jam dan diperpanjang $3 \times 24$ jam. Seperti halnya kasus penangkapan Ibrahim alias Ahim, yang ditangkap oleh Polsekta Banjarmasin Barat melebihi batas waktu penangkapan yang diatur dalam Pasal 19 ayat (1) KUHAP. Ibrahim alias Ahim bersama dengan tim kuasa hukumnya mengajukan Pra Peradilan, karena menilai penangkapan yang dilakukan terhadapnya tidak sesuai dengan hukum acara. Hal itu dikarenakan sejak Ahim ditangkap pada tanggal 17 November 2017, baru dikeluarkan surat perintah penahanan tanggal 20 November 2017.Sehingga jelas hal ini terjadi pelanggaran hukum karena telah lewat satu hari dan dengan sendirinya penangkapan dianggap tidak sah dan konsekuensinya tersangka harus dibebaskan demi hukum. ${ }^{33}$

Kasus serupa juga dialami politisi Andi Arif pada hari minggu tanggal 03 Maret 2019 dikamar Hotel Peninsula Jakarta Barat, hanya terhitung 3 hari sejak dilakukan penangkapan oleh aparat kepolisian. ${ }^{34}$ Kepala Biro Penerangan Masyarakat Divisi Humas Polri Brigjen Dedi Prasetyo mengatakan penyidik memiliki waktu $3 \times 24$ jam untuk menetapkan status Wakil Sekretaris Jenderal Partai Demokrat Andi Arief dalam kasus penyalahgunaan narkoba tersebut. ${ }^{35}$

\footnotetext{
33 "Tersangka Kasus Narkotika Praperadilankan Polsekta Banjarmasin Barat" ,https://kalsel.antaranews.com/berita/61530/tersangka-kasus-narkotika-praperadilkan-polsekta-banjarmasinbarat\#mobile-src, diakses tanggal 04 Maret 2020.

34 "Kasus Narkoba Andi Arief Cuma 3 Hari, Sudah Dibebaskan - IPW Menduga Ada Faktor Kedekatan Jenderal",https://www.tribunnews.com/mpr-ri/2019/03/07/kasus-narkoba-andi-arief-cuma-3-hari-sudahdibebaskan-ipw-menduga-ada-faktor-kedekatan-jenderal, diakses tanggal 04 Maret 2020.

35 "Polisi Miliki Waktu 3 x 24 Jam Tentukan Status Hukum Andi Arief", https://www.cnnindonesia.com/nasional/20190305132557-12-374619/polisi-miliki-waktu-3x24-jam-tentukanstatus-hukum-andi-arief, diakses tanggal 04 Maret 2020.
} 
Seharusnya penyidik Polri hanya berhak melakukan penangkapan $1 \times 24$ jam saja sesuai dengan Pasal 19 ayat (1) KUHAP, bukan enam hari sebagaimana kewenangan yang dimiliki penyidik BNN. Alasan yang dikemukakan oleh penyidik Polri dalam melakukan penyidikan tindak pidana narkotika, bahwa dalam jangka waktu penangkapan $1 \times 24$ jam tersebut tidak cukup untuk melakukan pemeriksaan serta mengungkap jaringan narkotika (kejahatan terorganisasi). ${ }^{36}$ Wisnu Chandra selaku Kepala Bidang Pemberantasan BNN Provinsi Jawa Timur, berpendapat bahwa:

Kewenangan yang diberikan kepada penyidik BNN tidak serta merta juga berlaku kepada penyidik Polri. Undang-Undang Narkotika membatasi kewenangan penyidik Polri, dengan mengatur secara tegas kewenangan penyidik BNN yang diatur dalam Pasal 75 UU No. 35 Tahun 2009 tentang Narkotika. Kesalahan pelaksanaan ini, dikarenakan tersangka maupun advokad banyak yang tidak mengetahui aturan hukum mengenai kewenangan penyidik BNN dan Polri terkait jangka waktu penangkapan. Sehingga dalam pelaksanaanya, penyidik Polri menggunakan kewenangan penyidik BNN yaitu jangka waktu $3 \times 24$ jam dan diperpanjang $3 \times 24$ jam. ${ }^{37}$

Penyidik Polri dalam melakukan kewenangan penangkapan menyimpang dari ketentuan hukum acara dan tidak sesuai dengan prinsip the right of due process. Hak due procces dalam tindakan penegakan hukum, bersumber dari citacita "Negara Hukum" yang menjunjung tinggi "supremasi hukum" (the law is supreme), 38 sehingga menimbulkan akibat hukum yaitu penangkapan yang telah dilakukan dengan sendirinya dianggap tidak sah karena melebihi batas waktu yang sudah ditentukan.

Bertitik tolak dari asas ini, Polri dalam melaksanakan fungsi dan kewenangan "penyidikan" harus sesuai dengan ketentuan hukum acara. Penyidik Polri dalam melakukan fungsi upaya paksa penangkapan terhadap pelaku Tindak Pidana Narkotika harus berpatokan dan berpegang pada Hukum Acara Pidana (criminal procedure) dalam hal ini KUHAP (Undang-Undang Nomor 8 Tahun 1981 tentang Hukum Acara Pidana).

\footnotetext{
36 Wawancara dengan Samsul Makali, Kepala Bagian Pembinaan dan Urusan Operasional Direktorat Reserse Narkotika Polda Jawa Timur, Tanggal 31 Mei 2019, di Direktorat Reserse Narkotika Polda Jawa Timur.

37 Wawancara dengan Wisnu Chandra, Kepala Bidang Pemberantasan BNN Provinsi Jawa Timur, Tanggal 31 Mei 2019 di Kantor BNN Provinsi Jawa Timur.

38 Yahya Harahap, Op. Cit., hlm. 95.
} 


\section{Harmonisasi Hukum sebagai Solusi dalam Pengaturan Upaya Paksa Penangkapan Terhadap Pelaku Tindak Pidana Narkotika}

Adanya perbedaan pengaturan upaya paksa penangkapan terhadap pelaku tidak pidana narkotika, maka diperlukan upaya untuk mengharmonisasikan perbedaan tersebut, dengan pengaturan upaya paksa penangkapan yang sama antara penyidik BNN dan penyidik Polri yaitu 3 × 24 jam dan dapat di perpanjang $3 \times 24$ jam, serta pengaturan pelaksanaan upaya paksa tindak pidana narkotika diatur diluar KUHAP, mengingat UU No. 35 Tahun 2009 tentang Narkotika merupakan Lex Specialis dari KUHAP. Sehingga hal ini akan mencegah terjadinya perbedaan penafsiran dalam pelaksanaan upaya paksa penangkapan bagi pelaku tindak pidana narkotika oleh Penyidik BNN dan Polri serta mencegah ketidakpastian hukum dan pelanggaran prinsip persamaan di hadapan hukum.

Pada kegiatan menyerasikan hubungan antara penyidik BNN dan Polri, tentunya perlu memandang pengaturan yang telah diterapkan pada Penegakan Hukum Terpadu (Gakkumdu) yaitu sebagai sentra penegakan hukum terpadu yang memiliki peran penting dalam penanganan tindak pidana pilkada, dibentuknya Gakkumdu bermaksud untuk menyamakan pemahaman dan pola penanganan tindak pidana Pilkada oleh Bawaslu, Kepolisian Negara Republik Indonesia, dan Kejaksaan Agung Republik Indonesia. ${ }^{39}$

Dengan adanya harmonisasi pengaturan antara penyidik BNN dan Polri dalam pelaksanaan upaya paksa sebagaimana dimaksud di atas, selain mencegah terjadinya perbedaan penafsiran dalam pelaksanaan upaya paksa penangkapan bagi pelaku tindak pidana narkotika oleh Penyidik BNN dan Polri serta mencegah ketidakpastian hukum dan pelanggaran prinsip persamaan di hadapan hukum, hal ini juga mencegah terjadinya tumpang tindih kewenangan antara penyidik BNN dengan penyidik Polri.

\section{Penutup}

Penelitian ini menyimpulkan sebagai berikut: pertama, adanya perbedaan pengaturan kewenangan upaya paksa penangkapan antara penyidik BNN dan Polri.

39 Edwied Febrian Safitri, Analisis Peran Sentra Penegakan Hukum Terpadu (Gakkumdu) dalam Penanggulangan Tindak Pidana Pemilihan Kepala Daerah, Skripsi, Fakultas Hukum Universitas Lampung, Bandar Lampung, 2019, hlm. 4. 
BNN diberikan waktu penangkapanpaling lama $3 \times 24$ jam dan dapat diperpanjang 3 x 24 jam, yang secara tegas diatur dalam Pasal 75 huruf g jo. Pasal 76 UU No. 35 Tahun 2009 tentang Narkotika. Sedangkan penyidik Polri berwenang melakukan penangkapan sesuai Pasal 16 jo. Pasal 19 KUHAP, yaitu 1 x 24 jam. Perbedaan pengaturan kewenangan upaya paksa penangkapan antara penyidik BNN dan Polri ini, mengakibatkan adanya suatu implikasi terhadap perbedaan pengaturan upaya paksa penangkapan bagi pelaku tindak pidana narkotika, yakni memicu perbedaan penafsiran dalam pelaksanaannya dan ketidakpastian hukum serta melanggar prinsip persamaan di hadapan hukum. Kedua, adanya disharmonisasi pengaturan upaya paksa penangkapan terhadap pelaku tindak pidana narkotika oleh penyidik BNN dan Polri, sehingga perlu kiranya diharmonisasikan berdasarkan KUHAP yang digariskan merupakan "sistem terpadu" (integrated criminal justice system). Sistem terpadu tersebut diletakkan di atas landasan prinsip "diferensiasi fungsional" di antara penegak hukum sesuai dengan "tahap proses kewenangan" yang diberikan undang-undang dan tunduk pada prinsip the right of due process.

Berpijak pada hasil penelitian dan analisa serta kesimpulan seperti yang dijelaskan diatas maka dapat direkomendasikan sebagai berikut: pertama, mengenai batas waktu penangkapan perlu dilakukan perubahan dengan mengatur kewenangan penangkapan yang sama yaitu $3 \times 24$ jam dan dapat di perpanjang $3 \times 24$ jam, serta pengaturan pelaksanaan upaya paksa tindak pidana narkotika diatur diluar KUHAP, mengingat UU No. 35 Tahun 2009 tentang Narkotika merupakan Lex Specialis dari KUHAP. Kedua, diperlukan penjernihan tegas dan pengaturan yang harmonis antara fungsi dan wewenang penyidik BNN dan penyidik Polri, seperti halnya pada Sentra Penegakan Hukum Terpadu (Gakkumdu) yang dibentuk dengan maksud untuk menyamakan pemahaman dan pola penanganan tindak pidana Pilkada oleh Bawaslu, Kepolisian Negara Republik Indonesia, dan Kejaksaan Agung Republik Indonesia.

\section{Daftar Pustaka}

\section{Buku}

Edyyono, Supriyadi Widodo, et al., Memperkuat Revisi Undang-Undang Narkotika Indonesia Usulan Masyarakat Sipil. Institute for Criminal Justice Reform, Jakarta, 2017. 
Gunawan, Ricky, et al, Membongkar Praktik Pelanggaran Hak Tersangka di Tingkat Penyidikan: Studi Kasus Terhadap Tersangka Kasus Narkotia di Jakarta, Lembaga Bantuan Hukum Masyarakat (LBH Masyarakat), Jakarta, 2012.

Harahap, M. Yahya, Pembahasan Permasalahan dan Penerapan KUHAP, Edisi 2, Cetakan 14, Sinar Grafika. Jakarta, 2012.

Ibrahim, Johnny dan Efendi, Jonaedi, Metode Penelitian Hukum Normatif dan Empiris, Prenada Media Group, Jakarta, 2016.

Muhammad, Abdulkadir, Hukum dan Penelitian Hukum, PT. Citra Aditya Bakti, Bandung, 2004.

Purnama, Ketut Adi, Transparansi Penyidik Polri dalam Sistem Peradilan Pidana di Indonesia, Cet.1, Bandung, PT Refika Aditama, Bandung, 2018.

Sujono, AR. dan Daniel, Boy, Komentar dan Pembahasan Undang-Undang Nomor 35 Tentang Narjotika, Sinar Grafika, Jakarta, 2011.

Siswanto, Politik Hukum dalam Undang-Undang Narkotika (UU Nomor 35 Tahun 2009), Rineka Cipta, Jakarta, 2012.

\section{Hasil Penelitian/Tugas Akhir}

Edwied Febrian Safitri, Analisis Peran Sentra Penegakan Hukum Terpadu (Gakkumdu) dalam Penanggulangan Tindak Pidana Pemilihan Kepala Daerah, Skripsi, Fakultas Hukum Universitas Lampung, Bandar Lampung, 2019

\section{Jurnal}

Dian Puspita Rini, "Kajian Normatif Mengenai Kewenagan Penangkapan oleh Penyidik BNN dan Penyidik Polri Terhadap Tersangka Tindak Pidana Narkotika", Jurnal Ilmiah Hukum Universitas Brawijaya, Mei, 2015.

Leni Pratiwi, "Harmonisasi dan Sinkronisasi Hukum terhadap Perbedaan Pengaturan Barang Impor dalam Keadaan Baru", Jurnal Ius Quia Iustum, Vol. 25 No. 1, Januari 2018.

M. Sahid, "Rekonstruksi Kewenangan Penyidikan Badan Narkotika Nasional Berdasarkan Undang-Undang Nomor 35 Tahun 2009 Tentang Narkotika", Arena Hukum, Vol 7, No 3, 2014.

Shinta Agustina, "Implementasi Asas Lex Specialis Derogat Legi Generali dalam Sistem Peradilan Pidana", Jurnal Masalah-Masalah Hukum, Vol. 44, No. 4, 2015.

Yoga Teguh Santoso, "Kewenangan Penyidik Tindak Pidana Narkotika antara Polisi Republik Indonesia dan Badan Narkotika Nasional (Menurut Undang-Undang Nomor 8 Tahun 1981 Kitab Undang-Undang Acara Pidana dan Undang-Undang No, 35 Tahun 2009 Tentang Narkotika)", Jurnal Hukum Universitas Brawijaya, Juni 2017. 


\section{Peraturan Perundang-undangan}

Undang-Undang Nomor 8 Tahun 1981 tentang Hukum Acara Pidana, (Lembaran Negara Republik Indonesia Tahun 1981 Nomor 1981);

Undang-Undang No. 35 Tahun 2009 tentang Narkotika, (Lembaran Negara Republik Indonesia Tahun 2009 Nomor 143);

Undang-Undang Nomor 2 Tahun 2002 tentang Kepolisian Negara Republik Indonesia (Lembaran Negara Republik Indonesia Tahun 2002 Nomor 4168);

Peraturan Pemerintah Nomor 58 Tahun 2010tentang Perubahan atas Peraturan Pemerintah Nomor 27 Tahun 1983 tentang Pelaksanaan Kitab UndangUndang Hukum Acara Pidana (Lembaran Negara Republik Indonesia Tahun 2010 Nomor 90);

Peraturan Kepala BNN RI No.1 Tahun 2009 tentang Syarat dan Cara Pengangkatan dan Pemberhentian Penyidik Badan Narkotika Nasional.

\section{Internet}

"Tersangka Kasus Narkotika Praperadilankan Polsekta Banjarmasin Barat", https://kalsel.antaranews.com/berita/61530/tersangka-kasus-narkotikapraperadilkan-polsekta-banjarmasin-barat\#mobile-src, diakses tanggal 04 Maret 2020.

"Kasus Narkoba Andi Arief Cuma 3 Hari, Sudah Dibebaskan - IPW Menduga Ada Faktor Kedekatan Jenderal",https://www.tribunnews.com/mprri/2019/03/07/kasus-narkoba-andi-arief-cuma-3-hari-sudah-dibebaskanipw-menduga-ada-faktor-kedekatan-jenderal, diakses tanggal 04 Maret 2020.

"Polisi Miliki Waktu 3x24 Jam Tentukan Status Hukum Andi Arief", https: / /www.cnnindonesia.com/nasional/20190305132557-12-

374619/polisi-miliki-waktu-3x24-jam-tentukan-status-hukum-andi-arief, diakses tanggal 04 Maret 2020.

"Polri dan BNN perlu Pembagian Kerja Jelas" https://www.republika.co.id/ berita/breaking-news/nasional/11/03/14/169312-polri-dan-bnn-perlupembagian-kerja-jelas, diakses tanggal 04 Maret 2020.

"Beberapa Catatan RUU KUHAP dalam Hubungannya dengan Pemberantasan Tindak Pidana Korupsi - Eddy O.S Hiariej", https://antikorupsi. org/sites/default/files/doc/Umum/Eddy $\% 200 S \% 20$ Hiariej-

Beberapa $\% 20$ Catatan $\% 20$ RUU $\% 20$ KUHAP $\% 20$ dalam $\% 20$ Hubungannya $\%$ 20dengan $\% 20$ Pemberantasan $\% 20$ Tindak\%20Pidana $\% 20$ Korupsi.pdf, diakses tanggal 25 Maret 2020.

\section{Wawancara}

Wawancara dengan Wisnu Chandra, Kepala Bidang Pemberantasan BNN Provinsi Jawa Timur, Tanggal 31 Mei 2019 di Kantor BNN Provinsi Jawa Timur. 
Wawancara dengan Samsul Makali, Kepala Bagian Pembinaan dan Urusan Operasional Direktorat Reserse Narkotika Polda Jawa Timur, Tanggal 31 Mei 2019, di Direktorat Reserse Narkotika Polda Jawa Timur. 